\title{
Ephrin Type-A Receptor 5
}

National Cancer Institute

\section{Source}

National Cancer Institute. Ephrin Type-A Receptor 5. NCI Thesaurus. Code C128879.

Ephrin type-A receptor 5 (1037 aa, $\sim 115 \mathrm{kDa}$ ) is encoded by the human EPHA5 gene. This protein is involved in tyrosine phosphorylation, cell-cell signaling and central nervous system development. 